\title{
Pelatihan peningkatan value ekonomi dan lingkungan pondok pesantren untuk sustainability di era society $\mathbf{5 . 0}$
}

\author{
Yunia Amelia ${ }^{1}$, Yuliansyah ${ }^{2}$,Andri Winata ${ }^{3}$.
} Universitas Lampung ${ }^{1,2}$, IIB Darmajaya ${ }^{3}$ yuliansyah@feb.unila.ac.id ${ }^{1}$,yunia.amelia@feb.unila.ac.id ${ }^{2}$ andriwinata@darmajaya.ac.id ${ }^{3}$

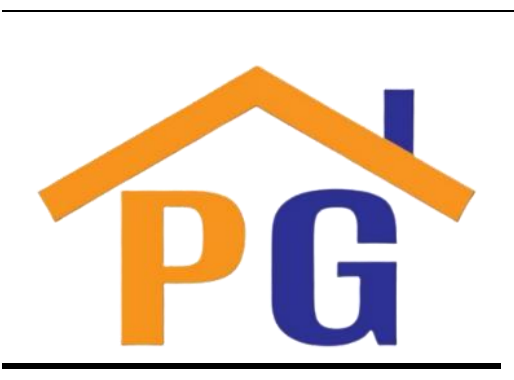

Riwayat Artikel

Diterima pada 09 Agustus 2020 Revisi 1 pada 23 Agustus 2020 Revisi 2 pada 26 Agustus 2020 Revisi 3 pada 28 Agustus 2020 Revisi 4 pada 30 Agustus 2020 Disetujui pada 31 Agustus 2020

\begin{abstract}
Abstrak:
Tujuan Kegiatan pengabdian ini melatih santri dan pengelola untuk memanfaatkan potensi yang ada di lingkungan sekitarnya untuk dapat menjadi salah satu sumber arus kas masuk bagi pesantren maupun bagi kesejahteraan santri yang sebagaian berasal dari keluarga yang tidak mampu. Lingkungan disekitar pesantren jika dikelola dengan benar dapat menghasilkan sesuatu yang bermanfaat untuk menjadi salah satu sumber pemasukan bernilai ekonomis. Adapun metode yang dilakukan berupa pelatihan dan pendampingan dengan materi potensi pengoptimalan pemanfaatan lingkungan berpotensi ekonomi, pengelolaan arus kas masuk dan keluar serta manajemen keuangan. Luaran dari hasil pengabdian ini adalah meningkatkan skill dan pengetahuan santri dan pengelola pondok untuk meningkatkan value ekonominya dengan tetap menjaga kelestarian lingkungan di sekitar pondok dengan memberikan skill pelatihan pengelolaan keuangan dan lingkungan bernilai ekonomis dengan memanfaatkan berbagai potensi yang ada dilingkungannya agar dapat meningkatkan kesejahteraan pondok dan santrinya. Kegiatan ini telah dilaksanakan Pada Hari Sabtu tanggal 8 Agustus dan 15 Agustus dengan narasumber Tim Dosen Pengabdian dari Fakultas Ekonomi dan Bisnis Universitas Lampung bertempat di Pondok Pesantren dihadiri 60 peserta. Hasilnya terjadi peningkatan pengetahuan rata-rata 40 persen dari peserta mengenai materi yang diberikan.
\end{abstract}

Kata kunci: pelatihan manajemen, value ekonomi, value lingkungan, sustainability

\section{PENDAHULUAN}

Situasi di Lokasi Mitra Pengabdian saat ini masih banyak lahan-lahan yang tidak dimanfaatkan untuk menjadi sumber penghasilan bagi santri maupun pengelola dan dibiarkan tidak produktif. Hasil pra survey baik pengelola maupun santri belum memiliki keterampilan dan skill didalam pemanfaatan lahan yang ada agar dapat menjadi sumber pendapatan. Secara spesifik mitra pengabdian membutuhkan pengetahuan didalam perhitungan biaya dan teknis dalam pemanfaatan potensi yang ada dilingkungannya agar dapat bernilai ekonomis.

Dalam menghadapi revolusi 4.0 dan akan menghadapi revolusi society 5.0 dimana persaingan akan semakin kompetitif, maka terwujudnya skill santri yang baik dalam memprediksi berbagai peluang yang ada untuk meningkatkan potensi ekonomi agar kesejahteraan semakin meningkat penting menjadi fokus perhatian berbagai pihak. Kemampuan santri dalam melihat peluang ekonomi yang bernilai tambah merupakan kunci sukses santri saat akan memasuki dunia kerja dan bersaing di pasar global. Hasil Penelitian dari Lestari ditemukan bahwa pelatihan dan kegiatan perlu dilakukan, untuk menunjang proses pertumbuhan jiwa kewirausahaan santri (Lestari, 2019). Menurut Budiyono pendidikan kewirausahaan yang diharapkan bisa menjadi solusi atas permasalahan tersebut ternyata kurang memperoleh perhatian yang cukup memadai, baik oleh dunia pendidikan, masyarakat, maupun 
pemerintah (Budiyono, 2017). Hasil pengamatan menunjukkan bahwa pada umumnya santri dalam pondok pesantren memiliki ketekunan dan kemauan didalam membuka lapangan usaha baru selulus dari pendidikannya, dengan demikian penting memiliki pondasi pengelolaan keuangan yang baik sebagai bekal nanti saat terjun ke dunia kerja yang kompetitif. Menurut Hamzah terdapat banyak pondok pesantren yang pada saat ini bisa bertahan tetap pada sumber daya yang mereka miliki untuk menjalankan kegiatan pondoknya (Hamzah, 2015). Walaupun menurut hasil penelitian belum ada metode pembelajaran yang konseptual dan praktek kewirausahaan yang diterima oleh santri secara efisien. Sebenarnya banyak sekali unit usaha yang dimiliki oleh pesantren yang dapat dimanfaatkan sebagai media pembelajaran kewirausahaan santri, sehingga santri yang memiliki bakat kewirausahaan dapat terlatih mentalnya. Namun pada realitanya unit usaha tersebut belum terdapat manajemen yang mengarah kepada pelatihan kewirausahaan santri (Anwarrosid, 2020).

Hasil dari pengabdian ini dalam bentuk pengetahuan dan wawasan sebagai bekal pengelola pesantren bersinergi dengan santri untuk merancang berbagai strategi untuk meningkatan kemampuan pengelolaan arus kas agar dapat mempertahankan kelangsungan pondok dan kinerja pondoknya terutama untuk memenuhi kecukupan financial. Oleh karena itu tim pengabdian dari Fakultas Ekonomi Unila bermaksud mengadakan pelatihan bagi santri dan pengelola untuk meningkatkan value ekonomi dan lingkungan pondok pesantren untuk sustainability di era society 5.0. Kondisi lingkungan sekitar pesantren masih banyaknya lahan yang dapat dioptimalkan sebagai value ekonomi dan lingkungan.

Secara umum, mitra pondok pesantren menghadapi permasalahan yang hampir serupa, yaitu pertama masih minimnya pengetahuan santri dan pengelola mengenai Potensi pengoptimalan pemanfaatan lingkungan berpotensi ekonomi. Kedua masih minimnya pengetahuan santri mengenai Pengelolaan arus kas masuk dan keluar. Ketiga masih minimnya wawasan dan pengetahuan mitra sasaran yaitu santri dan pengelola pondok mengenai manajemen keuangan dan kewirausahaan untuk hadapi tantangan di era revolusi 5.0. Upaya pesantren dalam pendidikan entrepreneurship merupakan langkah positif dalam mendorong para santri memiliki keterampilan sehingga hal tesebut dapat menjadi life skill setelah mereka keluar dari pesantren (Adawiyah, 2018).

Tujuan kegiatan pengabdian kepada masyarakat ini adalah untuk meningkatkan pengetahuan santri mengenai pengelolaan dan pemaanfaatan potensi lingkungan agar dapat menjadi value untuk dapat menjadi salah satu sumber pendapatan; meningkatkan pengetahuan pengetahuan manajemen pondok dalam pengelolaan arus kas keuangan untuk meningkatkan value ekonomi; meningkatkan wawasan dan pengetahuan mitra yaitu santri dan pengelola pondok mengenai tantangan di era revolusi 5.0.

Manfaat kegiatan pengabdian kepada masyarakat ini adalah bertambahnya pengetahuan santri mengenai pengelolaan dan pemaanfaatan potensi lingkungan agar dapat menjadi value untuk dapat menjadi salah satu sumber pendapatan; bertambahnya pengetahuan manajemen pondok dalam pengelolaan arus kas keuangan untuk meningkatkan value ekonomi; meningkatkan wawasan dan pengetahuan mitra yaitu santri dan pengelola pondok mengenai tantangan di era revolusi 5.0. Hasil penelitian khamidah menunjukan bahwa proses pendidikan kewirausahaan dan life skill dapat berjalan lancar dan maju karena adaya faktor pendukung dari dalam pesantren itu sendiri.(Khamidah, 2018). Manajemen kewirausahaan adalah salah satu proses memampukan dan memandirikan daya dan kekuatan yang ada guna membangun serta menentukan tindakan berdasarkan keinginan mereka secara mandiri dengan mengubah pola pikir agar menjadi berani dalam mengambil resiko dalam berwirausaha (Amri, 2020). Hasil penelitian Hafidh dan Badarudin menemukan bahwa inisiatif ekonomi yang dilakukan oleh pesantren adalah peternakan, perikanan, pertambangan, pertanian dan pengolahan limbah. Inisiatif tersebut berdampak positif bagi pesantren karena menjadi sumber dana lain untuk mendukung pembangunan pesantren tanpa sepenuhnya bergantung pada dukungan pemerintah. Bisnis tersebut juga membawa dampak positif bagi masyarakat di sekitar pesantren(Hafidh \& Badrudin, 2018).

\section{METODE}

Kegiatan pelatihan dan pendampingan dilaksanakan dalam dua tahap, pada minggu ke-2 dan ke-3 Agustus 2020, bertempat di Lokasi pondok pesantren di Desa Tanjung Sari dan Desa Way Ratai dengan narasumber Tim Dosen Pengabdian dari Fakultas Ekonomi dan Bisnis dan Universitas Lampung dibantu satu narasumber mengenai entrepreneurship. Adapun materi yang akan disampaikan adalah langkah-langkah Pengelolaan arus kas untuk meningkatkan value ekonomi. Pemanfaatan potensi 
lingkungan agar dapat menjadi sumber pendapatan. Menghadapi tantangan di era society 5.0 untuk sustainability dengan metode pelatihan dan pendampingan.

Untuk menumbuhkan jiwa entrepreneurship santri dilakukan beberapa pola pertama identifikasi kebutuhan pelatihan bagi santri dan organisasi, penetapan sasaran dan perancangan program untuk mencapai sasaran (Badruzzaman, 2009). Pembentukan jiwa entrepreneur santri di Pondok Pesantren Nurul Huda di antaranya adalah program seminar dan pelatihan, magang, dan program motivasi. Program tersebut diarahkan untuk membentuk jiwa wirausahawan muslim, meliputi: memiliki visi dan tujuan yang jelas, inisiatif dan selalu proaktif, berorientasi pada prestasi, kerja keras, bertanggung jawab, mengembangkan dan memelihara hubungan baik dengan berbagai pihak, berani mengambil risiko, jujur, mempunyai tujuan jangka panjang, dan selalu berdoa kepada Allah (Sangadah, 2019).untuk itu tim pengabdian akan melakukan tahapan langkah-langkah yang ditempuh guna melaksanakan solusi atas permasalahan spesifik yang dihadapi oleh mitra dapat dijabarkan sebagai berikut:

1. Penyiapan materi, alat dan peralatan pendukung media pelatihan dan pendampingan.

2. Penjadualan waktu dan pelaksanaan pelatihan dan pendampingan.

3. Pelaksanaan kegiatan pelatihan dan pendampingan.

4. Evaluasi kegiatan pelatihan dan pendampingan.

5. Pembuatan laporan pelatihan dan pendampingan.

6. Pembuatan artikel publikasi

Pihak-pihak yang terlihat dalam dalam kegiatan tersebut; Mitra pengabdian Pengelola dan Santri Pondok Pesantren; mahasiswa untuk membantu dalam proses penyiapan untuk pelaksanaan pelatihan; dosen sebagai narasumber pelatihan; alumni untuk membantu tim pengabdian memberikan pendampingan lanjutan yang juga merupakan dosen Kewirausahaan.

Mitra bersedia bekerjasama dengan mengikuti pelatihan yang akan diberikan oleh tim pengabdian dan melaksanakan hasil rekomendasi dari tim pengabdian untuk dapat diterapkan sebagai upaya pondok pesantren meningkatkan nilai value ekonomi dari lingkungan sekitarnya.

Dengan adanya kegiatan pengabdian ini masalah Masih minimnya pengetahuan pengetahuan manajemen pondok dalam pengelolaan arus kas keuangan untuk meningkatkan value ekonomi dan rendahnya pengetahuan santri mengenai pengelolaan dan pemaanfaatan potensi lingkungan agar dapat menjadi value untuk dapat menjadi salah satu sumber pendapatan dan tantangan bagi pondok pesantren di era revolusi 5.0 dapat ditingkatkan agar mendorong tercapainya peningkatan kesejahteraan dalam ekonomi bagi santri dan pondok, tetapi juga dapat memperkuat kelestarian lingkungan. Keberlanjutan program dapat dilakukan melalui pendampingan secara rutin untuk melihat apakah materi yang disampaikan dapat diimplementasikan dengan baik oleh mitra.

\section{HASIL DAN PEMBAHASAN}

Jadwal kegiatan pengabdian kepada Masyarakat meliputi kegiatan persiapan, pelaksanaan dan penyusunan laporan penelitian. Jadwal pelaksanaan mengacu pada Metode Pemecahan Masalah. Kegiatan pengabdian kepada masyarakat ini direncanakan melalui tahapan-tahapan sebagai berikut:

1. Rapat perencanan kegiatan yang dihadiri oleh seluruh anggota tim pengabdian

2. Tahap selanjutnya, masing-masing anggota tim mempersiapkan materi sesuai dengan bidangnya masing-masing, dan menghubungi narasumber ahli lainnya untuk mengisi salah satu materi pengabdian.

3. Melakukan kontak awal dan berkomunikasi dengan Pimpinan Pondok Pesantren untuk mempersiapkan pelaksanaan kegiatan, akhirnya disepakati pelaksanaan kegiatan pengabdian di Lokasi Pesantren dengan peserta santri, pengurus dan pengelola Pondok Pesantren.

4. Berkoordinasi dengan Pimpinan Pondok Pesantren untuk menggunakan aula, masjid dan lapangan pondok pesantren menjadi tempat pelaksaan kegiatan.

5. Mengirimkan surat ke seorang narasumber ahli tanaman untuk menjadi salah satu narasumber kegiatan terkait edukasi kegiatan penanaman pohon.

6. Pelaksanaan kegiatan pelatihan dan pendampingan di dua lokasi mitra kegiatan pengabdian.

7. Penyusunan Laporan dan pembuatan artikel untuk dipublikasikan dan disajikan dalam seminar. 
Pelaksanaan kegiatan dilakukan pada hari Sabtu, tanggal 8 Agustus 2020 pukul $09.00-16.00$ WIB dihadiri oleh peserta sejumlah 34 orang, dan Sabtu, 15 Agustus 2020. Kegiatan ini dibantu oleh panitia dari mitra maupun pelaksana kegiatan dan narasumber seluruh tim pengabdian. Personalia pengusul kegiatan pengabdian ini merupakan dosen dari akuntansi yang mengampu mata kuliah akuntansi sosial dan lingkungan, akuntansi biaya, akuntansi manajemen dan akuntansi keuangan, dan memberikan materi mengenai arus kas dalam pondok pesantren bagaimana penerimaan dan pengeluaran kas dari yayasan pondok pesantren selama periode laporan tertentu. Kas dan setara kas diklasifikasikan menjadi arus kas dari operasi, investasi, dan pendanaan. Arus kas dari operasi disajikan dengan metode tidak langsung.dikarenakan kegagalan pesantren dalam pengelolaannya dapat mengakibatkan terhentinya operasional pesantren. Pondok Modern juga melakukan pengembangan ekonomi pesantren melalui pembangunan unit-unit usaha (Fauzi, 2019) sehingga pesantren dapat value yang berniai ekonomi Teori nilai dalam ilmu ekonomi merupakan teori yang mencoba menjelaskan asal nilai suatu barang dan jasa, mengapa sesuatu berharga dan dapat diperdagangkan pada harga tertentu, serta bagaimana manusia bisa memperoleh keuntungan.

Materi yang diberikan pertama, langkah-langkah Pengelolaan arus kas untuk meningkatkan value ekonomi. Laporan keuangan arus kas (cash flow statement) memiliki pengertian sebagai laporan keuangan yang menyajikan informasi tentang penerimaan dan pengeluaran kas suatu perusahaan selama suatu periode, hal yang biasa disajikan atau digambarkan dalam laporan keuangan arus kas (Cash Flow Statement) meliputi jumlah kas yang diterima, seperti pendapatan tunai dan investasi tunai dari pemilik serta jumlah kas yang dikeluarkan perusahaan, seperti beban-beban yang harus dikeluarkan, pembayaran utang, dan pengambilan prive. Arus kas dalam pondok pesantren memberikan informasi mengenai penerimaan dan pengeluaran kas dari yayasan pondok pesantren selama periode laporan tertentu. Kas dan setara kas diklasifikasikan menjadi arus kas dari operasi, investasi, dan pendanaan. Arus kas dari operasi disajikan dengan metode tidak langsung. Kegagalan pesantren dalam pengelolaannya dapat mengakibatkan terhentinya operasional pesantren.

Kedua pemanfaatan potensi lingkungan agar dapat menjadi sumber pendapatan, dengan materi mengenai praktik langsung dilapangan bagaimana cara menanam pohon-pohon berpotensi ekonomi di lingkungan sekitar pesantren. Teori nilai dalam ilmu ekonomi merupakan teori yang mencoba menjelaskan asal nilai suatu barang dan jasa, mengapa sesuatu berharga dan dapat diperdagangkan pada harga tertentu, serta bagaimana manusia bisa memperoleh keuntungan.

Ketiga materi mengenai bagaimana menghadapi tantangan di era society 5.0 untuk sustainability pondok pesantren dengan ilmu entrepreneuship untuk dapat memiliki bekal manajemen kewirusahaan baik bagi pengeola pondok maupun santri untuk melindungi lingkungan dan mengurangi konsumsi daya pondok dapat dengan mematikan perangkat elektronik. Bisnis diatur untuk mencegah polusi dan menjaga agar emisi karbon rendah. Ada insentif untuk memasang sumber daya terbarukan di lingkungan pondok. Perlindungan lingkungan adalah pilar ketiga dan bagi banyak orang, perhatian utama masa depan umat manusia. Ini mendefinisikan bagaimana santri dan pengelola harus mempelajari dan melindungi ekosistem, kualitas udara , integritas, dan keberlanjutan sumber daya alam dan berfokus pada elemen-elemen yang memberi dampak pada lingkungan. Ini juga menyangkut bagaimana teknologi akan mendorong masa depan kita yang lebih hijau; EPA mengakui bahwa pengembangan teknologi dan bioteknologi adalah kunci keberlanjutan dan melindungi lingkungan di masa depan dari potensi kerusakan yang dapat ditimbulkan oleh kemajuan teknologi.

Perkembangan teknologi maju semakin pesat maka peran sumber daya manusia saat ini banyak yang tergantikan oleh kehadiran robot cerdas, bahkan dianggap hal tersebut dapat mendegradasi peran manusia. Hal ini yang melatarbelakangi lahirnya revolusi Society 5.0. Secara sederhana, Society 5.0 dapat diartikan sebagai suatu konsep masyarakat yang berpusat pada manusia (human-centered) dan berbasis teknologi (technology based). Konsep ini menyebabkan manusia tidak kehilangan perannya dalam era digital. Manusia sebagai masyarakat tetap hidup sebagai pusat peradaban. Oleh karena itu, perlu adanya regulasi untuk melindungi pekerja dari ancaman kehilangan pekerjaan. Sebab, Revolusi Industri 4.0 adalah keniscayaan yang tidak bisa dihentikan. Tetapi pemerintah harus melakukan langkah-langkah untuk menghindari dampak terburuk bagi kaum buruh, apalagi ditengah bonus demografi yang dihadapi oleh indonesia di tahun 2035. Untuk itulah society 5.0 adalah jawaban atas masalah yang timbul di era revolusi industri 4.0, dimana manusia sebagai pusat perdaban yg berbasis teknologi. Jangan sampai terbalik manusia menjadi korban teknologi yang tumbuh berkembang. Fokus 
dalam Society 5.0 menjadi peluang besar bagi Indonesia untuk mempercepat transformasi masyarakatnya dalam segala bidang.

Dampak pelatihan memberikan bekal bagi para santri tentang aspek managerial skill, production technical skill, dan personality develovmental skill. Intinya adalah menanamkan sikap dan semangat mandiri serta kemampuan kerjasama dan tertanamnya paradigma kewirausahaan bagi para santri (Hidayat, 2016). Motivasi pengembangan dan pematangan karir di pondok perlu diberikan pembekalan dasar-dasar ilmu kewirausahaan agar lebih efektif dengan bekal ilmu kewirausahaan menjadi modal dan cara yang terbaik menuju seorang wirausahawan yang sukses.(Almuin, Solihatun, \& Haryono, 2017). Hasil penelitian pondok pesantren bisa dijadikan model dua pengembangan ekonomi pondok pesantren di bidang agraria. Pertama konvensional; yakni dengan lebih cenderung menjual langsung hasil pertanian kepada tengkulak atau pedagang besar seperti atau model kedua Modern; dengan cara mengolah sendiri hasil pertanian dan perkebunan tersebut sehingga memiliki nilai jual yang lebih bagus dibandingkan langsung dijual.(Mardyanto, 2016).

\section{KESIMPULAN DAN SARAN}

Hasil pengabdian yang dilaksanakan secara keseluruhan, kenaikan pengetahuan dan pemahaman peserta pelatihan rata-rata 40 persen dari keseluruhan peserta. Sedangkan kenaikan sebesar 0 persen dialami oleh 5 peserta yang tetap belum memahami mengenai materi yang disampaikan dan merasa kurang cukup waktunya, membutuhkan penjelasan secara lebih intens. Dari 64 peserta kegiatan ratarata belum pernah mengikuti pelatihan sejenis. Madrasah santripreneur merupakan model pengembangan pemberdayaan kewirausahaan santri yang memadukan empat unsur utama pesantren yaitu: kyai, santri, kurikulum, infrastruktur. Keempat unsur yang ada di pondok pesantren Darussalam memiliki potensi yang cukup besar. Potensi ini dapat dioptimalkan ketika keempat unsur saling bersinergi (Hilyatin, 2016).

\section{Ucapan terima kasih}

Tim Pengabdian mengucapan terima kasih pada Lembafa Penelitian dan Pengabdian pada Masyarakat Universitas Lampung, Seluruh Santri dan Pengelola Pondok Pesantren Darul Iman dan Pondok Pesantren. Al Hidayah.

\section{REFERENSI}

Adawiyah, S. R. (2018). PENDIDIKAN KEWIRAUSAHAAN DI PONDOK PESANTREN

SIROJUL HUDA. Comm-Edu (Community Education .... Retrieved from

http://journal.ikipsiliwangi.ac.id/index.php/comm-edu/article/view/661

Almuin, N., Solihatun, S., \& Haryono, S. (2017). Motivasi Pengembangan dan Pematangan Karir Kewirausahaan di Pondok Pesantren (Kajian di Pondok Pesantren Al-Rabbani Cikeas). Sosio EKons. Retrieved from http://journal.lppmunindra.ac.id/index.php/sosio_ekons/article/view/1686

Amri, F. (2020). Manajemen kewirausahaan di Pondok Pesantren Roudlotut Tholibin 28 Purwosari Kota Metro. repository.metrouniv.ac.id. Retrieved from http://repository.metrouniv.ac.id/id/eprint/3747/

Anwarrosid, M. F. (2020). Upaya Pengembangan Kewirausahaan Santri Melalui Unit Usaha Di Pondok Pesantren Wali Songo Ngabar Ponorogo. etheses.iainponorogo.ac.id. Retrieved from http://etheses.iainponorogo.ac.id/10561/

Badruzzaman, D. F. (2009). Pemberdayaan kewirausahaan terhadap santri di pondok pesantren: Studi kasus Pondok Pesantren Al-Ashriyyah Nurul Iman Parung, Bogor. repository.uinjkt.ac.id. Retrieved from http://repository.uinjkt.ac.id/dspace/bitstream/123456789/18159/1/DEDEN FAJAR BADRUZZAMAN-FSH.pdf

Budiyono, B. (2017). Implementasi pendidikan kewirausahaan di Pondok Pesantren Sabilun Najah Seputih Raman Lampung Tengah. repository.radenintan.ac.id. Retrieved from http://repository.radenintan.ac.id/1324/

Fauzi, M. (2019). Fundraising Ziswaf dan Kewirausahaan di Pondok Pesantren Modern Tazakka, Batang, Jawa Tengah. Jurnal Bingkai Ekonomi. Retrieved from http://itbsemarang.ac.id/jbe/index.php/jbe33/article/view/71

Hafidh, Z., \& Badrudin, B. (2018). Pesantren dan Kemandirian Perekonomian: Studi tentang Kewirausahaan di Pondok Pesantren Ar-Risalah Cijantung IV Ciamis. Manageria: Jurnal 
Manajemen .... Retrieved from http://ejournal.uin-

suka.ac.id/tarbiyah/index.php/manageria/article/view/2238

Hamzah, S. N. A. (2015). ... kewirausahaan berbasis agrobisnis: Studi multi-kasus di Pondok Pesantren Mukmin Mandiri Sidoarjo dan Pondok Pesantren Nurul Karomah Pamekasan .... etheses.uin-malang.ac.id. Retrieved from http://etheses.uin-malang.ac.id/id/eprint/3286

Hidayat, D. (2016). Pelatihan Kewirausahaan Untuk Pemberdayaan Kelompok Pemuda Produktif Di Pondok Pesantren Ihyahul Khoer. Journal of Nonformal Education and Community .... Retrieved from https://journal.unnes.ac.id/sju/index.php/jnfc/article/view/10658

Hilyatin, D. L. (2016). Pemberdayaan Kewirausahaan Santri Berbasis Madrasah Santripreneur di Pondok Pesantren Darussalam. Al-Amwal: Jurnal Ekonomi Dan Perbankan Syari'ah. Retrieved from http://www.syekhnurjati.ac.id/jurnal/index.php/amwal/article/view/202

Khamidah, N. (2018). Pendidikan kewirausahaan untuk meningkatkan life skill santri di Yayasan Pondok Pesantren Modern Yatim dan Dhuafa Madania Yogyakarta. dspace.uii.ac.id. Retrieved from https://dspace.uii.ac.id/handle/123456789/8479

Lestari, C. (2019). PENANAMAN JIWA KEWIRAUSAHAAN DI PONDOK PESANTREN BANI ROSUL PURWOKERTO BARAT. repository.iainpurwokerto.ac.id. Retrieved from http://repository.iainpurwokerto.ac.id/id/eprint/5358

Mardyanto, E. (2016). Manajemen Kewirausahaan Pondok Pesantren Berbasis Agrobisnis (Studi Kasus di PP Mukmin Mandiri dan PP Nurul Karomah). FIKROH: Jurnal Pemikiran Dan .... Retrieved from http://jurnal.stai-alazharmenganti.ac.id/index.php/fikroh/article/view/28

Sangadah, N. I. M. (2019). MANAJEMEN PENDIDIKAN KEWIRAUSAHAAN AGROBISNIS DI PONDOK PESANTREN NURUL HUDA LANGGONGSARI KECAMATAN CILONGOK KABUPATEN .... repository.iainpurwokerto.ac.id. Retrieved from http://repository.iainpurwokerto.ac.id/5429/ 